\title{
Pharmaciana
}

Vol.11, No.1, March 2021, Page. 15-24

ISSN: 2088 4559; e-ISSN: 24770256

DOI: $10.12928 /$ pharmaciana.v11i1.17875

\section{Isolation and identification of secondary metabolites in ethyl acetate extract from the Maja bark (Aegle marmelos Linn.)}

\author{
Muhammad Syahrir*', Eka Bungin Kadola , Pince Salempa \\ Chemistry Department, Faculty of Natural Sciences and Mathematics, Makassar State University, \\ Jl. Dg. Tata 2 Parang Tambung, Makasar, Indonesia
}

Submitted: 04-09-2020 Reviewed: 01-12-2020 Accepted: 29-03-2021

\begin{abstract}
This exploratory study resulted in the isolation and identification of secondary metabolites in ethyl acetate extracts from the Maja bark (Aegle marmelos Linn.) from Pattappa Village, Pujananting Subregency, Barru Regency, South Sulawesi. The stages of isolation included maceration, fractionation, and purification. Maceration was performed with methanol, fractionation with ethyl acetate, a particular ratio of acetone (9:1) was used, and purification was done by flowing nitrogen gaseous into the $\mathrm{E}_{5}$ fraction. Furthermore, the classification test and FTIR spectrophotometer were carried out for identification. Pure isolates in the form of white crystals were obtained with a melting point of $242^{\circ} \mathrm{C}$. Reagent tests indicated a brown precipitate on Wagner's test and a white precipitate on Mayer's test. Infrared-spectrophotometric identification provided typical absorption for such functional groups as $\mathrm{NH}$, aliphatic $\mathrm{CH}$, aromatic $\mathrm{C}=\mathrm{C}$, and amine CN. The reagent tests and FTIR-spectrophotometer identification confirmed that the secondary metabolites fit well into the class of alkaloids.
\end{abstract}

Keywords: Aegle marmelos (Linn.), alkaloids and secondary metabolites

*Corresponding author:

Muhammad Syahrir

Chemistry Department, Faculty of Natural Sciences and Mathematics, Makassar State University

J1. Dg. Tata 2 Parang Tambung

Email: m.syahrir7406@unm.ac.id 


\section{INTRODUCTION}

Many natural compounds in Indonesia are widely used in therapeutic and health-enhancing properties. From traditional remedies until becoming the community's habits, natural ingredients, which are believed to cure various diseases, have been developed and used as pesticides, dyes, and medicines. Due to the uneven geographic and taxonomic distribution of plants, the success of a research program that aims to find new bioactive compounds with a unique and novel molecular structure still depends on biological resources (Achmad et al., 2001). One of the natural plantbased remedies is the Maja plant, commonly known as bael (Aegle marmelos linn.), a tribe of oranges or Rutaceae, which is native to Asian tropics and subtropics (Sastrohamidjojo, 1996); (Salempa, 2014).

Maja (Aegle marmelos linn) is a type of medicinal plant found in Indonesia's tropical forests. This tropical plant can be developed as a source of secondary metabolite compounds for medicinal substances. Commonly, Maja plants are known by various names such as Maja, Bila Gedang, Bilabila, Bilak, and Bila peak. The plant is widespread in Indonesia because its growth suits the climate of all parts of Indonesia (Sastrohamidjojo, 1996).

Several regions in Indonesia have acknowledged numerous benefits of the Maja plant and included it in traditional medicine. Maja is a traditional medicinal plant to overcome various diseases. Currently, many Maja medicinal plants have been used to develop traditional medicines. However, Maja's information to treat multiple diseases has not been fully collected. Hence, it is challenging to identify the Maja plant's primary uses by gathering all literature data from the internet (Mulyaningsih et al., 2020).

Maja fruit (Aegle marmelos $(L)$ correa) is one type of plant that is considered unique among Indonesians. The legendary Majapahit comes from Maja and Pahit (Indonesian phrase for bitter taste), which means Maja fruit that tastes bitter. It turns out that other parts of Maja plant hold a myriad of extraordinary benefits for health. It was used as traditional medicines such as for fever, constipation, dysentery, diarrhea, hepatitis, tuberculosis, inflammation of the nasal mucous membranes, brain disorders, liver disorders, itching (scabies, ulcers, boils, eczema), antiinflammatory, hearing loss, urinary disorders, and abortive (Tasyrifah, 2010). The Maja fruit is also helpful as an anti-inflammatory and larvicidal (Harborne, 1987; $\mathrm{Ng}$ et al., 2018; Sari and Susilowati, 1981; Subhasini, 2014). Various phytopharmacological evaluations also have been reported for the important potential of the Aegle marmelos (Sanghi and Mushtaq, 2017).

The leaf extracts of Aegle marmelos (L.) Correa showed the presence of terpenoids, steroids, phytosterols, tannins, alkaloids, glycosides, saponins, reducing sugars, phenols, and flavonoids (Snehlata et al., 2018). Tannins may be used to cure urinary disorder, fever (antipyretic), swelling, vomiting, cuts, ulcers, thiamine deficiencies, diabetes mellitus, diarrhea, dysentery, and wound. It may also function as an anti-toxic substance, vegetable insecticides for stink bugs (Leptocorisa acuta). As a traditional medicine, its leaf may be boiled and then be drunk to reduce high blood pressure or hypertension (Mulyaningsih et al., 2020).

The result of phytochemical analysis has shown the presence of steroid compounds in the bark of Aegle marmelos linn. Some steroids act as an anti-inflammatory or to reduce inflammation. The skin of the Aegle marmelos Linn contains coumarin derivatives, and the sturucture appears as $R-(+)$-marmine based on the X-ray diffraction (Gupta et al., 2006). Previous work by Riyanto (2003) had subjected Maja leaves to extraction method using petroleum ether and chloroform, resulting in an aegeline compound, N-2-hydroxy-2(4-methoxyphenyl ethyl cinnamamide) were obtained. Such compounds were found to be cinnamic acid-derivative alkaloids.

According to previous research (Wilujeng et al., 2020), the antioxidant activity test result of the Maja fruit extract samples was profound, with the $\mathrm{IC}_{50}$ values reaching the range of 50-100 $\mu \mathrm{g} / \mathrm{mL}$. Trials on mice were also carried out and proven to reduce their blood sugar levels. Interestingly, the study results had produced Maja fruit beverage that no longer tastes bitter but 
changes the taste to be rather sweet, warmer when drinking it as its natural alcohol levels are reasonably safe for the body.

This study sought to show the potential secondary metabolites in the Maja bark similar to the prior work. The earlier mentioned descriptions showed that it is essential to find secondary metabolite in Maja bark to be used as an active ingredient in pharmacy by applying ethyl acetate solvent. The stem of the plant is one part that has a high possibility to be isolated since such part is expected to produce novel secondary metabolites and is often used by the community as traditional medicine.

\section{MATERIALS AND METHOD}

Material

The equipment used for the research includes FTIR Spectrophotometer Shimadzu Prestige21. The identification of isolate was taken on a Shimadzu IR Prestige-21 using $\mathrm{KBr}$ pellets in the range of $4500-500 \mathrm{~cm}^{-1}$ wavenumber from which functional groups of the compound were obtained.

\section{Test and procedure}

As much as $4.5 \mathrm{~kg}$ of Maja bark was grounded and macerated with methanol solvent for $3 \times 24$ hours (Tobo et al., 2001), and the extract was harvested for 1x24 hours. Prior to weighing, the macerate was filtered through the Büchner funnel with Whatman filter and was evaporated using a rotary evaporator until the methanol extract thickened (Harborne, 1987). After weighing, the methanol extract was partitioned using liquid-liquid extraction with a separatory funnel and ethyl acetate solvent. The resulting filtrate was evaporated to be dried at room temperature and then weighed.

Ethyl acetate extract was fractionated using Vacuum Liquid Chromatography (VLC) method. The TLC's result was analyzed using Thin-Layer Chromatography (TLC) to obtain fractions of the same staining profiles. These fractions were combined and evaporated at room temperature. One of the fractions was selected and fractionated using Pressure Column Chromatography (PCC). The resulting fraction of PCC was, once again, analyzed using TLC, where fractions of the same staining profiles were combined. Fractions that indicated the presence of crystals at this point were recrystallized to obtain pure crystals. The purification of the fractions was subjected to three eluent systems. The compounds' isolation resulted from the qualitative test with suitable reagents, e.g., Lieberman-Burchard, $\mathrm{FeCl}_{3}$, Wagner's, and Mayer's reagents. The melting points were examined by using the Melting Point Meter, and the functional groups were tested using an FTIR spectrophotometer.

\section{RESULT AND DISCUSSION}

\section{Classification test}

The identification of ethyl acetate extract's chemical content was tested using such reagents as $\mathrm{FeCl}_{3}$, Liebermann-Buchard, Mayer, and Wagner. This test aimed to identify the class of secondary metabolites present in ethyl acetate extract. The result was presented in Table 1 
Table 1. The classification test result of ethyl acetate extract

\begin{tabular}{lll}
\multicolumn{1}{c}{ Reagents } & Result & Description \\
\hline Wagner & $\begin{array}{l}\text { Brown } \\
\text { precipitate }\end{array}$ & (+) Alkaloids \\
Mayer & Yellow & (-) Alkaloids \\
$\mathrm{FeCl}_{3}$ & Green & (+) Flavonoids \\
$\begin{array}{l}\text { Lieberman- } \\
\text { Burchard }\end{array}$ & Green & (+) Steroids \\
\hline
\end{tabular}

\section{Fractionation and purification}

The fractionation process involved a stationary phase composed of $60 \mathrm{H}$ silica gel and a mobile phase where eluents gradually increased in polarity. Separation was carried out based on color bands found in the stationary phase. It obtained 27 fractions, as shown in Table 2.

Table 2. The results of vacuum liquid-column chromatography

\begin{tabular}{clcl}
\hline Fraction & \multicolumn{1}{c}{ Eluent } & Ratio $(\%)$ & Color \\
\hline $1-2$ & n-hexane & 100 & Clear \\
$3-5$ & n-hexane:ethyl acetate & $9: 1$ & Clear \\
$6-8$ & n-hexane:ethyl acetate & $8: 2$ & Green \\
$9-11$ & n-hexane:ethyl acetate & $7: 3$ & Green \\
12 & n-hexane:ethyl acetate & $6: 4$ & Green \\
13 & n-hexane:ethyl acetate & $5: 5$ & Green \\
14 & n-hexane:ethyl acetate & $4: 6$ & Yellow \\
15 & n-hexane:ethyl acetate & $2: 8$ & Yellow \\
16 & Ethyl acetate & 100 & Yellow \\
17 & Ethyl acetate:acetone & $9: 1$ & Yellow \\
$18-19$ & Ethyl acetate:acetone & $7: 3$ & Yellow \\
20 & Ethyl acetate:acetone & $6: 4$ & Yellow \\
21 & Ethyl acetate:acetone & $4: 6$ & Yellow \\
22 & Ethyl acetate:acetone & $2: 8$ & Yellow \\
$23-24$ & Ethyl acetate:acetone & $1: 9$ & Brown \\
25 & Acetone & 100 & Brown \\
$26-27$ & Methanol & 100 & Brown \\
\hline
\end{tabular}

Fractions that revealed the same staining profiles were combined and grouped into ten fractions. Fraction E that weighed $1.9526 \mathrm{~g}$ was further fractionated using PCC, from which 24 fractions were obtained (Firdaus, 2011), (Iwan and Darminto, 2012). Subsequent TLC was required for fraction combinations that consisted of 10 fractions according to the same staining profiles on TLC plates. The chosen fraction subjected to purification was fraction $\mathrm{E}_{5}$ (Table 3) which weighed $0.5208 \mathrm{~g}$. The resulting isolate was recrystallized with chloroform and methanol solvent that developed into a white crystal-forming isolate that weighed $43.1 \mathrm{mg}$. 
Table 3.Combination of pressed-column chromatography fractions, fraction $E$.

\begin{tabular}{ccc}
\hline Fraction & Combination & Weight $(\mathbf{g})$ \\
\hline 1 & $\mathrm{E}_{1}$ & 0.0128 \\
$2-3$ & $\mathrm{E}_{2}$ & 0.0085 \\
4 & $\mathrm{E}_{3}$ & 0.0047 \\
5 & $\mathrm{E}_{4}$ & 0.0180 \\
$\mathbf{6 - 7}$ & $\mathrm{E}_{5}$ & $\mathbf{0 . 5 2 0 8}$ \\
$8-11$ & $\mathrm{E}_{6}$ & 0.2975 \\
$12-14$ & $\mathrm{E}_{7}$ & 0.1564 \\
$15-17$ & $\mathrm{E}_{8}$ & 0.0225 \\
$18-20$ & $\mathrm{E}_{9}$ & 0.0394 \\
$21-24$ & $\mathrm{E}_{10}$ & 0.0106 \\
\hline
\end{tabular}

The purification of the $E_{5}$ isolate was carried out with repeated recrystallization. This technique aims to separate the isolates from the remaining impurities. The purification product was pure isolate (isolate $E_{5}$ ) in white crystals as much as $43.1 \mathrm{mg}$. The results of classification and spectroscopy tests that were previously reported corroborated this finding. Research conducted by (Nugroho et al., 2011) reported that aegeline (N-2-hydroxy-2(4-methoxyphenyl)ethylcinnamamide), as an alkaloid derived from cinnamic acid, was obtained in the petroleum ether extract and chloroform of Maja plant leaves. Anthraquinone (1-methyl -2-(3'-methyl-but-2'enyloxy), which has anti-fungal activity against Aspergilus fumigatus and Candida albicans, was isolated in Aegle marmelos correa seeds (Mirsha et al., 2010). The results of A. marmelos Correa isolation found a Coumarin, marmarin 7-(6'-7 'dihidroxygeranial-oxy), which actively inhibits leukemia cells (Nugroho et al., 2011). In another research, the highest concentration of marmelosin $(108.65 \mu \mathrm{g} / \mathrm{g})$ was observed in immature Maja fruit and the highest antibacterial activity of marmelosin against E. coli was shown at a concentration of $200 \mu \mathrm{g} / \mathrm{ml}$ by using the HPLC instrument (Svaefullah et al., 2020).

\section{Purification test}

The purity of the isolate was tested using three eluent systems where a pure isolate was indicated by a single spot's appearance when developed on a TLC plate. The result of the purity test with three eluent systems, i.e., n-hexane: acetone (3:7), chloroform: ethyl acetate (6:4), and nhexane: ethyl acetate (7:3), appeared as a single spot, thus confirming the purity of the isolates. The exact temperature at which melting point was determined, using melting point apparatus, was $242^{\circ} \mathrm{C}$ (Firdaus, 2011). The classification of the resulting isolates was tested using these reagents, as shown in Table 4.

Table 4 The result of classification of pure isolated fraction $\mathrm{E}_{5}$

\begin{tabular}{|c|c|c|}
\hline Reagents & $\begin{array}{l}\text { Color } \\
\text { Reaction } \\
\end{array}$ & Description \\
\hline Wagner & $\begin{array}{l}\text { Brown } \\
\text { precipitate }\end{array}$ & (+) Alkaloids \\
\hline Meyer & $\begin{array}{l}\text { White } \\
\text { precipitate }\end{array}$ & (+) Alkaloids \\
\hline $\mathrm{FeCl}_{3}$ & Yellow & (-) Flavonoids \\
\hline $\begin{array}{l}\text { Lieberman- } \\
\text { Burchard }\end{array}$ & Colorless & (-) Steroids \\
\hline
\end{tabular}

A pure isolate of fraction $\mathrm{E}_{5}$ was tested for purity by TLC three eluent systems. The isolate was visible after the $\mathrm{CeSO}_{4}$ stain was given, and the heating produced a brown color, as shown in Figure 1 . 


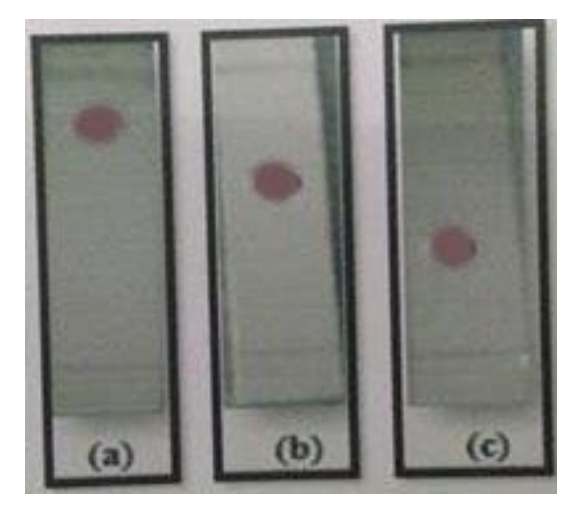

Figure 1. TLC Results of the isolate using Three Eluent Systems

(a). Eluent n-hexane : acetone

(b). Eluent chloroform : ethyl acetate

(c). Eluent n-hexane : ethyl acetate

The isolate was further tested for purity using TLC with three types of eluents that displayed comparisons between different solvents. This aimed to confirm the isolate's purity as the developed TLC plates each showed a single spot. In the wake of the TLC development (Atun, 2010), a single spot appeared on these eluents, i.e., combinations of n-hexane and acetone; combinations of chloroform and ethyl acetate; combinations of n-hexane and ethyl acetate. As for the melting point, the results show that these isolates began to melt at $240{ }^{\circ} \mathrm{C}$ and melted completely at $242{ }^{\circ} \mathrm{C}$. This supports the theory that a pure compound will have a sharp melting point, from solid-state to liquid-state, at no more than $2^{\circ} \mathrm{C}$ (Firdaus, 2011). The classification test led to positive alkaloid reactions to Wagner's reagent and Mayer's reagent, indicated by a brown-precipitate formation and a white-precipitate formation. This precipitate occurs because alkaloids are compounds from the nitrogenous base group. If the nitrogenous base is reacted with an acid, $\mathrm{HCl}$ (hydrochloric acid) will form an insoluble salt so that this salt will form a precipitate. In contrast, the difference in color that occurs is due to the original color of the used reagent. The three tests show that the Maja Bark (Aegle marmelos) extract was tested positive for alkaloids (Ibrahim and Rusdiaman, 2017).

\section{FTIR spectroscopy test}

Based on FTIR spectroscopy, the infrared spectrum of isolate $E_{5}$ was interpreted in terms of the wavenumber, band, intensity, and group, as shown in Figure 2. 


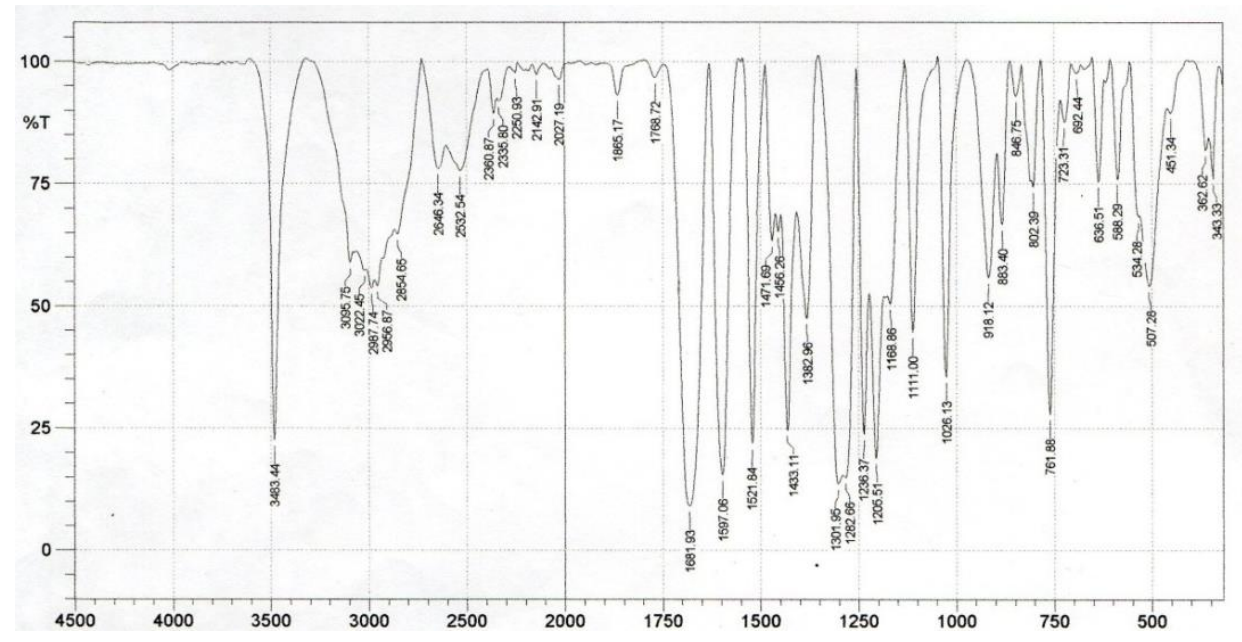

Figure 2. The infrared spectrum of pure isolate $E_{5}$

The IR spectrum analysis on isolated fraction $\mathrm{E}_{5}$ revealed functional groups such as N-H stretching vibration, seen on a sharp band of strong intensity at $3483.44 \mathrm{~cm}^{-1}$. This intense N-H vibration was confirmed by C-N stretch that exhibited absorption of 1236.37 and 1205.51 (ref.1250$1020 \mathrm{~cm}^{-1}$ ). Sharp absorption that exhibited low intensity at $2987.74,2956.87$, and $2854.65 \mathrm{~cm}^{-1}$ wavelengths was attributed to stretching vibration of $-\mathrm{CH}$ aliphatic $\left(\mathrm{CH}_{2}\right.$ and $\mathrm{CH}_{3}$ groups) (ref. $3000-2850 \mathrm{~cm}^{-1}$ ), thus indicating the presence of methyl and aliphatic methyl groups in isolated fraction $E_{5}$. Such indication was further confirmed by the presence of bending vibration in the region of 1433.11 and $1382.96 \mathrm{~cm}^{-1}$, a typical absorption band for bending vibration of germinal dimethyl group - or $\mathrm{CH}\left(\mathrm{CH}_{3}\right)_{2}$ group (ref.1450-1375 cm-1). Absorption at a wavenumber of 1681.93 accounted for the carbonyl group's $(\mathrm{C}=\mathrm{O})$ stretching vibration (ref.1715-1860 cm-1), affirmed by the low-intensity absorption of C-O in the region of 1301.95 and $1282.66 \mathrm{~cm}^{-1}$. The high-intensity absorption band at 1597.06 and 1521.84 wavelengths, which was aromatic $\mathrm{C}=\mathrm{C}$ (ref.1650-1450 cm-1) in the region of 1111.00 and $1026.13,35 \mathrm{~cm}^{-1}$, was specific to a functional group of ether (C-O-C) (Sastrohamidjojo, 1996) (Mohrig et al., 2010).

Based on the IR spectrum interpretation, several functional groups were indicated: amine $(\mathrm{N}$ $\mathrm{H})$, aliphatic $(\mathrm{C}-\mathrm{H})$, carboxylate groups $(\mathrm{HO}-\mathrm{C}=\mathrm{O})$, double-bond aromatic $(\mathrm{C}=\mathrm{C}), \mathrm{CN}$, and $\mathrm{COC}$. This indicates that isolate $\mathrm{E}_{5}$ is one of the alkaloid compounds group. It was confirmed by the group test results showing that the pure isolates were positive for the alkaloid group.

\section{CONCLUSION}

The isolation of secondary metabolites from ethyl acetate extracts from Maja bark indicated the presence of pure, white crystalline isolates of alkaloid type, which melted at $242{ }^{\circ} \mathrm{C}$.

\section{ACKNOWLEDGEMENT}

The authors would like to show gratitude to Dr.Netti Herawati, S.Pd., M.Si., Coordinator of Organic Laboratory Research Chemistry Faculty of Mathematics and Natural Science Makassar State University, for providing the facilities during the research had done. We are also immensely grateful to Akmal, S.Si., for his valuable contributions to support this research.

\section{REFERENCES}

Achmad, S. A., Hakim, E. H., Erwin, S. M., Nario, A., Mariko, K., Lukman, M., \& Hiromitsu, T. (2001). Artoindonesianin B suatu senyawa yang bersifat toksik terhadap sel tumor P-388 dari tumbuhan Artocarpus altilis. Bulletin The Indonesian Society of Natural Product Chemistry, 20-27

Atun, S. (2010). Pemanfaatan bahan alam menuju riset internasional. 1-15 
Firdaus. (2011). Teknik dalam laboratorium kimia organik (p. 108). Prodi Kimia Jurusan Kimia FMIPA Universitas Hasanuddin

Gupta, V. K., Goswami, S., \& B.D.Gupta. (2006). Crystal structure of R-(+)-marmin. Analytical Sciences, 22, X11-X12

Harborne J.B. (1987). Metode Fitokimia. Insitut Teknologi Bandung

Ibrahim, H. I., \& Rusdiaman. (2017). Identifikasi senyawa alkaloid daging buah maja (Aegle marmelos) asal batu bessi kabupaten barru Sulawesi Selatan. Media Farmasi, XIII(1), 105110

Iwan D, \& Darminto. (2012). Kimia organik bahan alam: metode isolasi dan identifikasi senyawa kimia organik metabolit sekunder Dari Bahan Alam. Jurusan Kimia FMIPA Universitas Negeri Makassar

Mirsha, B. B., Navneet Kishore, Vinod K.Tiwari, D.Singh, D., \& Tripathi, V. (2010). A novel anti fungal anthraquinone from seeds of Aegle marmelos correa (Family rutaceae). Fitoterapia, 81, 104-107

Mohrig, J. R., Hammong, C. N., \& F.Schatz, P. (2010). Techniques in organic chemistry (Third Edit). United States of America

Mulyaningsih, A. P., Yetti, R. D., \& Rivai, H. (2020). Phytochemical and pharmacological review of maja ( Aegle Marmelos ). World Journal of Farmacy and Pharmaceutical Science, 9(9), 19-42. https://doi.org/10.20959/wjpps20209-17045

Ng, R. C., Kassim, N. K., Yunie Soon, Y. Y., Gwendoline Cheng, L. E., Yazan, S. L., \& Musa, K. H. (2018). Isolation of carbazole alkaloids and coumarins from aegle marmelos and murraya koenigii and their antioxidant properties. Sains Malaysiana, 47(8), 1749-1756. https://doi.org/10.17576/jsm-2018-4708-14

Nugroho, A. E., Riyanto, S., Sukari, M. A., \& Maeyama, K. (2011). Anti-allergic effects of marmin, a coumarine isolated from Aegle marmelos Correa: In vitro study. International Journal of Phytomedicine, 3(1), 84-97

Riyanto, S. (2003). Pytochemical studies and bioactivity tests of murraya paniculata jack, Aegle marmelos Correa, and Zingiber amaricans Blume. University Putra Malaysia

Salempa, P. (2014). Isolasi dan identifikasi senyawa metabolit sekunder ekstrak n-Heksan daun tumbuhan maja ( Aegle marmelos Linn .) isolation and identification of secondary metabolites compound contained n-hexane extract plant leaves ( Aegle marmelos Linn .). Jurnal Sainsmat, III(2), 185-190

Sanghi, S. B., \& Mushtaq, S. (2017). Aegle marmelos a potential medicinal tree: an overview. International Journal of Research Granthaalayah, 5(8), 63-66. https://doi.org/https://doi.org/10.29121/granthaalayah.v5.i8.2017.2183

Sari, M. P., \& Susilowati, R. P. (1981). Larvacide effication test of maja (Aegle Mormelos) leaves powder on aedes aegypti. In L. L. Herlina (Ed.), Journal of Chemical Information and Modeling (Vol. 53, Issue 9, pp. 1689-1699). Research Centre Unit, Medical Faculty of Lambung Mangkurat University

Sastrohamidjojo, H. (1996). Sintetis bahan alam. Gadjah Mada University Press

Snehlata, K., Sheel, R., \& Kumar, B. (2018). Evaluation of phytochemicals in polar and non polar solvent extracts of leaves of Aegle marmelos (L.). IOSR Journal of Biotechnology and Biochemistry (IOSR-JBB), 4(5), 31-38. https://doi.org/10.9790/264X-0405013138

Subhasini, R. A. G. R. (2014). In-vitro anti-inflammatory and mosquito larvicidal efficacy of nickel nanoparticles phytofabricated from aqueous leaf extracts of Aegle marmelos Correa. Acta Tropica, 135(July 2014), 19-26. https://doi.org/10.1016/j.actatropica.2014.03.012

Svaefullah, B. L., Erwanto, Y., Wihandovo, Muhlisin, Prasetvo, R. A., Kurniawati, N., \& Fitriyanto, N. A. (2020). Maja pruit extracts inhibit escherichia coli, reduce fly larvae population, and ammonia emission of chicken excreta. Tropical Animal Science Journal,

Pharmaciana Vol. 11, No. 1, March 2021, Page. 15 - 24 
43(4), 369-376. https://doi.org/10.5398/tasj.2020.43.4.369

Tasyrifah, M. (2010). Efek pemberian ekstrak daun maja ( Aegle Marmelos Corr. ) terhadap fertilitas tikus betina. Institut Pertanian Bogor

Tobo, F., Mufidah, Taebe, B., \& Mahmud, I. (2001). Buku pegangan laboratorium fitokimia I (ekstraksi komponen kimia bahan alam). Laboratorium Fitofarmasi Jurusan Farmasi, FMIPA Universitas Hasanuddin

Wilujeng, S., I, P. L., \& Tiaranisa, P. (2020). Antioxidant maja fruit ( Aegle marmelos ( L ) Carrea ) lowering blood sugar mus musculus. Budapest International Research in Exact Sciences Medical, Biological, Argiculture, Enginering Science and Other Related Areas, Volume 2,(L), 362-367. https://doi.org/https://doi.org/10.33258/birex.v2i3.1075 
